\title{
Effect of Seed Treatment and Seed Borne Mycoflora on Vigour of Mungbean [Vigna radiata (L.) Wilczek] Grown in Agro - Climatic Zones of Chhattisgarh, India
}

\author{
Santoshi Pradhan, N. Lakpale, P.K. Tiwari and Ashish Pradhan* \\ Department of Plant Pathology, College of Agriculture, IGKV, Raipur (CG) 492012, India \\ *Corresponding author
}

\begin{tabular}{|c|c|}
\hline \multicolumn{2}{|r|}{ A B S T R A C T } \\
\hline & \multirow{5}{*}{$\begin{array}{l}\text { Mungbean is grown principally for its protein content. Seed borne mycoflora affect the } \\
\text { germination and vigour of seeds. Thus, due to seed borne diseases, there is a reduction in } \\
\text { the production, resulting in failure of fulfilling the demand of mungbean seeds. The } \\
\text { associated seed borne mycoflora were found to reduce the germination and thereby } \\
\text { seedling vigour index. Fungicides and Trichoderma were found to increase the vigour } \\
\text { index by keeping mycoflora under check and plant growth promoting activities of } \\
\text { Trichoderma. Seedling vigour was markedly reduced by some of the seed borne mycoflora } \\
\text { when evaluated by seed inoculation techniques. Rhizopus sp. }(68.14 \%) \text { shows overall } \\
\text { impact irrespective of seed lots followed by Fusarium sp. }(64.05 \%) \text {. Seedling showed } \\
\text { initial wilting type symptoms yielded Fusarium sp. and root rot like symptoms yielded } \\
\text { Rhizopus sp. upon isolation which was identical to both the fungi detected from mungbean } \\
\text { seeds. Hence, Rhizopus sp. and Fusarium sp. were found to be pathogenic to mungbean } \\
\text { seeds and seed transmissible in nature. It was also found that Macrophomina sp. reduces } \\
\text { the vigour index maximum irrespective of seed lots (56.63\%) followed by Penicillium sp. } \\
\text { (39.25\%) and Fusarium sp. (38.85\%) in comparison to control when soil inoculation } \\
\text { technique was used. }\end{array}$} \\
\hline $\begin{array}{l}\text { Mungbean, } \\
\text { Mycoflora, Seed } \\
\text { treatment, } \\
\text { Vigour index }\end{array}$ & \\
\hline Article Info & \\
\hline $\begin{array}{l}\text { Accepted: } \\
\text { 15 September } 2017 \\
\text { Available Online: } \\
10 \text { November } 2017\end{array}$ & \\
\hline & \\
\hline
\end{tabular}

\section{Introduction}

Among the pulses, mungbean is popularly known as green gram or golden gram is one of the most important short duration pulse grown in India. The seeds are highly nutritious as it contains about $23.86 \%$ protein, $62.6 \%$ carbohydrates, $1.15 \%$ fat, $5.27 \%$ crude fibre, $3.32 \%$ ash besides rich in lysine (436 $\mathrm{mg} / \mathrm{g}$ ). It is also rich in $\mathrm{Ca}, \mathrm{Fe}$, and $\mathrm{K}$ is a good source of vitamins such as thiamine, niacin and vitamin $\mathrm{A}$. The total area covered under mungbean in India was 30.41 lakh hectares with a total production of 14.24 lakh tonnes. The national yield average was 468 $\mathrm{kg} / \mathrm{ha}$. The lowest yield observed in the state of Karnataka (247 kg/ha) followed by Chhattisgarh (269 kg/ha) and Odisha (337 $\mathrm{kg} / \mathrm{ha}$ ) (Anon., 2016).

Contaminated seeds can often result in poor germination and poor seedling vigour, resulting in an un-healthy crop. Field fungus associated with seeds causes deterioration of seed quality, affect viability and reduces germination (Shrivastava and Gupta, 1981). The infected seeds fail to germinate or seedlings and plants developed in the field 
from infected seeds may escape early infection but may often be infected at the later stage of growth. Besides, pathogens can spread over a long distance and uninfected field may be infected by the seeds in which different pathogens are present (Fakir et al., 2001).

The seed borne pathogen associated with mungbean seeds externally or internally may caused seed rot, seedling blight and resulting into low germination. Some fungi are associated with testa and cotyledonary of seeds infected in form of mycelium and conidia (spores), after germination the infection transmitted to hypocotyls and stem bases as well as dicotyledonary leaves of seedling.

Some seed borne pathogens having ability to kill the seedling or plants and substantially reduce the productive capacity (Rahman et al., 1999). Seed mycoflora play an important role in determining the quality and longevity of seed.

Mungbean is subjected to several mycoflora which are seed borne, soil borne and air borne. Seed borne mycoflora associated with Mungbean reported include Macrophomina phaseolina, Aspergillus flavus, Colletotrichum sp., Drechslera sp., and Myrothecium sp. These fungi were negative effect on germination and vigour of seeds (Sarita et al., 2014).

Till date, seed health evaluation aspects like mycoflora associated their effect on seedling vigour index, transmission and management not studied well and documented of mungbean grown in all agro-climatic zones of Chhattisgarh. Therefore, an attempt was taken to carry out the present investigation to find out the effect of seed treatment and seed borne mycoflora on vigour of mungbean seeds.

\section{Materials and Methods}

\section{Effect of fungicidal seed treatment on seedling vigour of mungbean}

To find out the efficacy of seed dressing fungicides on seedling vigour, seed dressing fungicide viz. Bavistin (Carbendazim), Devithiram (Thiram 75\% WP), Safal (Carbendazim 12\% + Mencozeb 63\% WP), Mencozeb (Dithane M-45) and C.G. Tricocap (Trichoderma) were taken at their recommended dose along with a control (without treated). Treated and untreated seeds were grown in pots filled with sterilized soil. The seedling growth was assessed in terms of seedling vigour index 21 days after sowing. The germination percentage, root length and shoot length were recorded to calculate seedling vigour index of each treatment and seed samples. The shoot length measured from the base of the shoot to upper most leaf tip. For measuring the root length, plant was carefully uprooted first, gently washed and carefully placed on clean transparent glass piece. The length of root system was measured from collar region to the end of longest tip. The seedling vigour index was calculated by using the following formula given by Abdul- Baki and Anderson (1973)

Seedling vigour index $=($ Mean shoot length + Mean root length) $x$ Germination percentage

\section{Effect of seed borne mycoflora on seedling vigour by using seed inoculation technique}

Apparently healthy surface sterilized (1.0\% $\mathrm{NaOCl})$ mungbean seeds were taken for this study. The seeds were rolled on 7-10 days old sporulating culture of individual mycoflora thriving on PDA in Petri plate. The rolled seeds were grown in pots filled with sterilized soil. The seedling growth was assessed in term of seedling vigour index 21 days after sowing as described earlier. 
Effect of seed borne mycoflora on seedling vigour by using soil inoculation technique

All seed borne fungi detected in various methods used were grown separately and multiplied in sterilized wheat grain substrate. Substrate was inoculated with seven days old culture of individual fungus separately. The inoculated substrate was incubated at $25 \pm 2$ ${ }^{0} \mathrm{C}$ for ten days. Substrate was shaken every day to avoid clumping. The pots were filled with sterilized soil and infected by each mycoflora inoculum. For soil inoculation, upper four $\mathrm{cm}$ layer of the soil was thoroughly mixed with culture grown in wheat medium@10g / pot and watered to just wet the inoculated soil. Pots were kept in glass house for 72 hours for proper soil infection and establishment of mycoflora before sowing of mungbean seeds. Seeds were surface sterilized $(1.0 \% \mathrm{NaOCl})$ before sowing followed by three washing with sterile distilled water and were sown in inoculated soil @ 20 seeds per pot. A set of control was also kept with surface sterilized seeds sown in sterilized un-inoculated soil. Pots were watered at regular intervals. The seedling growth was assessed in term of seedling vigour index 21 days after sowing as described earlier.

\section{Results and Discussion}

\section{Effect of seed treatment on seedling vigour of mungbean seeds}

In glass house condition pot experiment was conducted to know the effect of different fungicides and bio control agent (Trichoderma) on the seedling vigour of mungbean seeds collected from five districts. Fungicide and Trichoderma treated and untreated seeds were sown in pre sterilized soil and observations were recorded for vigour index 21 days DAS. Data presented in table 1(a) shows that all the fungicides and
Trichoderma treated seeds had higher vigour index as compare to that of control.

Maximum seedling vigour index was recorded Raigarh district seed lot in C.G. Tricocap (2901.06\%) treatment which was 67.26 per cent more than that of control in of Raigarh district seed lot followed by Jagdalpur district in Devithiram (2716.66\%) which was 56.44 per cent more than that of control in Jagdalpur district. Least vigour index was recorded in Kawardha district $(898.32 \%)$ in control (untreated). This might due to presence of seed borne mycoflora in highest frequency which reduces the germination percentage and thereby seedling index. The above result clearly showed that fungicides and bio control agent Trichoderma taken in the study could be able to reduce the mycoflora associated with seeds and thereby increase the vigour index and in untreated seeds vigour index was less than the treated seeds.

Analysis of data presented in table 1(b) reveal that among fungicides, maximum mean increase in vigour index over control $(56.61 \%)$ was recorded in Mancozeb across the five seed lots treated. Interestingly, Trichoderma treated seeds of five seed lots of mungbean recorded second least mean increase in vigour index over control $(50.19 \%)$. This might be attributed that Trichoderma not only reduces seed borne mycoflora but also exhibit the plant growth promoting activity and thereby higher vigour index was recorded over control across the five seed lots tested.

It is clear from the above finding that seed borne mycoflora reduces the seedling vigour index whereas fungicidal and biocontrol agent Trichoderma increases the seedling vigour index by keeping seed borne mycoflora under check. Similar results were also reported by various researchers while working with seed 
health evaluation agreeing the finding of present study (Teama et al., (2000), Rahman et al., (2002), Singh et al., (2002), Sethuraman et al., (2003), Prajapati et al., (2003), Javaid and Anjum (2006), Rajeshwari and Kumari (2009), Dabbas et al., (2009), Mandhare et al., (2010), Pan et al., (2010), Geetanjali and Giri (2014), Suramwar et al., (2014), Ashwini and Giri (2014 a \& b), Kandhare (2014), Singh et al., (2014), Tak et al., (2015), Gawade et al., (2016), Shekhar (2016) and Fatma et al., (2017).

\section{Effect of seed borne mycoflora on seedling vigour by using seed inoculation technique}

It is depicted from data presented in table 2(a) and 2(b) that seedling vigour was markedly reduced by some of the seed borne mycoflora when evaluated by seed inoculation technique. Overall impact in reducing seedling vigour index was shown by Rhizopus sp. $(68.14 \%)$ followed by Fusarium sp. (64.05\%) across all five seed lots evaluated as compared to that of control. Maximum reduction in seed lot of Ambikapur district was caused by Rhizopus sp. (92.24\%) followed by Fusarium sp. (66.91\%) and Penicillium sp. (64.90\%). In seed lot of Balod district, reduction was maximum by Rhizopus sp. (44.13\%) followed by A. flavus (42.13\%) and Fusarium sp. (39.09\%). The reduction in seedling vigour index of seed lot of Jagdalpur was maximum by Rhizopus sp. (90.80\%) followed by Macrophomina sp. (79.90\%) and Fusarium sp. (63.23\%). Fusarium sp. caused maximum reduction in seedling vigour index of seed lot of Kawardha and Raigarh districts. ( $89 \%$ and $62.03 \%$, respectively) followed by Rhizopus sp. $(70.24 \%$ and $43.31 \%$, respectively). Reduction in seedling vigour may be attributed due to inhibition of germination of seed by inoculated mycoflora some of the weak seedling with light green colour leaves and reduced plumule and radical length or wilt like symptoms and rotting of roots of seedling were also noticed.

The underdeveloped symptoms shown by some of the seedling were subjected to isolation of mycoflora from infected plant / root tissues. Isolation from wilted type plant tissue yielded the fungus identical to with the Fusarium sp. which was isolated from seed sample. Similarly, isolation from infected root tissues yielded the fungus identical with the Rhizopus sp. which isolated from seed sample.

Table.1a Effect of seed treatment on seedling vigour index of mungbean seeds

\begin{tabular}{lllllll}
\hline S. & Treatment & \multicolumn{5}{c}{ District (seedling vigour index) } \\
\cline { 3 - 6 } & & Ambikapur & Balod & Jagdalpur & Kawardha & Raigarh \\
\hline 1 & $\begin{array}{l}\text { Carbendazim } \\
\text { (Bavistin) }\end{array}$ & 1922.76 & 2210.08 & 2106.8 & 1086.48 & 1769.88 \\
2 & Thiram (Devithiram) & 2351.72 & 2026.24 & 2716.66 & 1099.4 & 2403.28 \\
3 & $\begin{array}{l}\text { Mancozeb+ } \\
\text { Thiram (Safal) }\end{array}$ & 2206.26 & 2434.32 & 2369.84 & 2171.32 & 2374.4 \\
& & & & & \\
4 & $\begin{array}{l}\text { Mancozeb } \\
\text { (Dithane M- 45) }\end{array}$ & 2087.2 & 2346.08 & 2191.56 & 1297.72 & 1774.52 \\
5 & $\begin{array}{l}\text { Trichoderma } \\
\text { (C.G.Tricocap) }\end{array}$ & 2075.7 & 2549.38 & 2519.4 & 1538.22 & 2901.06 \\
6 & Control & 1764.18 & 1704.76 & 1734.3 & 898.32 & 1734.4 \\
\hline
\end{tabular}


Table.1b Effect of seed treatment on per cent increase over control of mungbean seeds

\begin{tabular}{|c|c|c|c|c|c|c|c|}
\hline \multirow{2}{*}{$\begin{array}{l}\mathbf{S} . \\
\mathbf{N} .\end{array}$} & \multirow[t]{2}{*}{ Treatment } & \multicolumn{6}{|c|}{ District $(\%)$ increase over control } \\
\hline & & Ambikapur & Balod & Jagdalpur & Kawardha & Raigarh & $\begin{array}{l}\text { Mean } \\
\text { increase } \\
\text { over control }\end{array}$ \\
\hline 1 & $\begin{array}{l}\text { Carbendazim } \\
\text { (Bavistin) }\end{array}$ & 8.98 & 29.64 & 21.47 & 20.94 & 2.04 & 16.61 \\
\hline 2 & $\begin{array}{l}\text { Thiram } \\
\text { (Devithiram) }\end{array}$ & 33.30 & 18.86 & 56.64 & 22.38 & 38.56 & 33.91 \\
\hline 3 & $\begin{array}{l}\text { Mancozeb+ } \\
\text { Thiram (Safal) }\end{array}$ & 25.05 & 42.79 & 36.64 & 141.70 & 36.90 & 56.61 \\
\hline 4 & $\begin{array}{l}\text { Mancozeb } \\
\text { (Dithane M- } \\
45 \text { ) }\end{array}$ & 18.30 & 37.61 & 26.36 & 44.46 & 2.31 & 25.80 \\
\hline 5 & $\begin{array}{l}\text { Trichoderma } \\
\text { (C.G.Tricocap) }\end{array}$ & 17.65 & 49.54 & 45.26 & 71.24 & 67.26 & 50.19 \\
\hline 6 & Control & - & - & - & - & - & - \\
\hline
\end{tabular}

Table.2a Effect of seed borne mycoflora on seedling vigour index by seed inoculation technique

\begin{tabular}{|c|c|c|c|c|c|c|}
\hline \multirow[t]{2}{*}{ S.N. } & \multirow[t]{2}{*}{ Mycoflora } & \multicolumn{5}{|c|}{ District (seedling vigour index) } \\
\hline & & Ambikapur & Balod & Jagdalpur & Kawardha & Raigarh \\
\hline 1 & A. flavus & 1848.6 & 1044.5 & 2148.5 & 2076.1 & 1902.6 \\
\hline 2 & A. niger & 2038.4 & 1608.75 & 1864.2 & 1485.0 & 2352.0 \\
\hline 3 & A.fumigatus & 1137.15 & 1410.6 & 1394.0 & 994.4 & 1685.2 \\
\hline 4 & Rhizopus sp. & 199.0 & 1008.4 & 201.0 & 646.5 & 1447.5 \\
\hline 5 & Macrophomina sp. & 1398.0 & 1528.8 & 439.4 & 762.85 & 2157.0 \\
\hline 6 & Penicillium sp. & 900.3 & 1448.5 & 2124.2 & 1745.7 & 1637.3 \\
\hline 7 & Fusarium sp. & 848.8 & 1099.35 & 803.95 & 238.95 & 969.5 \\
\hline 8 & Control & 2565.5 & 1805.05 & 2186.8 & 2172.8 & 2553.75 \\
\hline
\end{tabular}


Table.2b Effect of seed borne mycoflora on per cent decrease over control by seed inoculation technique

\begin{tabular}{|c|c|c|c|c|c|c|c|}
\hline \multirow[t]{2}{*}{ S.N. } & \multirow[t]{2}{*}{ Mycoflora } & \multicolumn{5}{|c|}{ District (decrease over control (\%) } & \multirow{2}{*}{$\begin{array}{l}\text { Mean } \\
\text { decrease } \\
\text { over } \\
\text { control }\end{array}$} \\
\hline & & Ambikapur & Balod & Jagdalpur & Kawardha & Raigarh & \\
\hline 1 & A. flavus & 27.94 & 42.13 & 1.75 & 4.45 & 25.49 & 31.75 \\
\hline 2 & A. niger & 20.54 & 10.87 & 14.75 & 31.65 & 7.90 & 18.3 \\
\hline 3 & A. fumigatus & 55.67 & 21.85 & 36.25 & 54.23 & 34.01 & 35.27 \\
\hline 4 & Rhizopus sp. & 92.24 & 44.13 & 90.80 & 70.24 & 43.31 & 30.64 \\
\hline 5 & Macrophomina sp. & 45.50 & 15.30 & 79.90 & 64.89 & 15.53 & 56.63 \\
\hline 6 & Penicillium sp. & 64.90 & 19.75 & 2.86 & 19.65 & 35.88 & 30.26 \\
\hline 7 & Fusarium sp. & 66.91 & 39.09 & 63.23 & 89.00 & 62.03 & 38.85 \\
\hline 8 & Control & - & - & - & - & - & - \\
\hline
\end{tabular}

Table.3a Effect of seed borne mycoflora on seedling vigour index by soil inoculation technique

\begin{tabular}{|c|c|c|c|c|c|c|}
\hline \multirow[t]{2}{*}{ S.N. } & \multirow[t]{2}{*}{ Mycoflora } & \multicolumn{5}{|c|}{ District (seedling vigour index) } \\
\hline & & Ambikapur & Balod & Jagdalpur & Kawardha & Raigarh \\
\hline 1 & A. flavus & 1643.4 & 1327.7 & 1659.6 & 985.05 & 2110.55 \\
\hline 2 & A. niger & 2161.6 & 1803.6 & 2094.4 & 1103.4 & 1993.8 \\
\hline 3 & A. fumigatus & 1480.05 & 1459.15 & 1494.0 & 1764.1 & 910.8 \\
\hline 4 & Rhizopus sp. & 1554.0 & 1506.7 & 1757.7 & 1512.6 & 1344.6 \\
\hline 5 & Macrophomina sp. & 1525.5 & 1342.0 & 413.7 & 374.1 & 1197.0 \\
\hline 6 & Penicillium sp. & 1273.05 & 1794.0 & 1319.85 & 657.45 & 1630.2 \\
\hline 7 & Fusarium sp. & 2140.8 & 1684.2 & 980.65 & 778.95 & 1230.6 \\
\hline 8 & Control & 2565.5 & 1805.05 & 2186.8 & 2172.8 & 2553.75 \\
\hline
\end{tabular}


Table.3b Effect of seed borne mycoflora on per cent decrease over control by soil inoculation technique

\begin{tabular}{llllllll}
\hline S.N. & Mycoflora & \multicolumn{5}{c}{ District (decrease over control(\%) } & \multicolumn{1}{c}{$\begin{array}{l}\text { Mean } \\
\text { decrease } \\
\text { over } \\
\text { control }\end{array}$} \\
\cline { 3 - 8 } & & Ambikapur & Balod & Jagdalpur & Kawardha & Raigarh \\
\hline 1 & A. flavus & 35.94 & 26.44 & 24.10 & 54.95 & 17.35 & 31.75 \\
2 & A. niger & 15.74 & 0.08 & 4.22 & 49.54 & 21.92 & 18.3 \\
3 & A. fumigatus & 42.30 & 19.16 & 31.24 & 19.32 & 64.33 & 35.27 \\
4 & Rhizopus sp. & 39.42 & 16.52 & 19.10 & 30.83 & 47.34 & 68.14 \\
5 & Macrophomina sp. & 40.53 & 25.65 & 80.96 & 82.89 & 53.12 & 56.63 \\
6 & Penicillium sp. & 50.37 & 0.61 & 39.25 & 69.93 & 36.16 & 39.26 \\
7 & Fusarium sp. & 16.55 & 6.69 & 54.86 & 64.37 & 51.81 & 64.05 \\
8 & Control & - & - & - & - & - & - \\
\hline
\end{tabular}

Hence, it was proved that the detected seed borne mycoflora namely Fusarium sp. and Rhizopus sp. were pathogenic to mungbean seed and observed seed transmissible in the present study. Brayford (1996) also observed that Fusarium solani transmitted via seed infected planting material or movement of soil. Rawal and Singh (2015) reported that, out of twelve seed borne mycoflora of opium poppy, three fungi $A$. alternata, $R$. solani and Fusarium solani were found pathogenic and seed to plant transmissible in nature.

Effect of seed borne mycoflora on seedling vigour by using soil inoculation technique

Soil inoculation technique was used to know the effect of seed borne mycoflora on seedling vigour index and data presented in table 3(a) and 3(b). It was clear from the table that Macrophomina sp. reduces the vigour index maximum irrespective of seed lots $(56.63 \%)$ followed by Penicillium sp. (39.25\%) and Fusarium sp. (38.85\%) in comparison to control. In Ambikapur seed lot, maximum reduction in seed lot was recorded by Penicillium sp. (50.37\%) followed by Macrophomina sp. (40.53\%). Aspergillus flavus reduces maximum vigour index (26.44\%) followed by Macrophomina sp. (25.65\%) in Balod district seed lot. In Jagdalpur district seed lot, maximum reduction in seedling vigour index was recorded in Macrophomina sp. (80.96\%) followed by Fusarium sp. (54.86\%). Macrophomina sp. reduces maximum vigour index $(82.89 \%)$ followed by Penicillium $\mathrm{sp}$. $(63.93 \%)$ in Kawardha district seed lot. In Raigarh district seed lot, reduction in seedling vigour index was maximum in A. fumigatus $(64.33 \%)$ followed by Macrophomina sp. $(53.12 \%)$.

These methods being quick and simple can be used in routine pathogenecity tests of fungal pathogens, both the methods are of equal importance.

It was observed that these fungi reduced the per cent seed germination and seedling vigour as reported by different workers (Prasad, 1983; 
Paul, 1992).

Many plant pathogenic fungi are known to produce phytotoxic metabolites (Vidhyasekaran et al., 1970). Importance of the production of such toxic metabolites is more obvious when the pathogen is seed borne because it may either inhibit seed germination or adversely affects the initial growth of seedlings.

It was observed that seed borne mycoflora inhibit the germination of mungbean seeds and retarded the growth of seedling may be due to production of metabolites. Similarly, Gandhi and Raghuchander (2001) also observed the effect of seed borne fungi on seed germination and seedling vigour of coriander. The reduction of seed germination and seedling vigour may be attributed to absorption, translocation and interference of toxic metabolites with routine biochemical activities of the seed and seedling during germination and growth of the seedling as evident by the work of Jain et al., (1996), and Prokinova and Buresova (1996).

\section{Acknowledgements}

This manuscript is the part of M.Sc. (Ag) thesis work. Hence, the authors would like to thank the Department of Plant Pathology, College of Agriculture, Indira Gandhi Krishi Vishwavidyalaya, Raipur, Chhattisgarh for the technical support.

\section{References}

Abdul Baki, A. and Anderson, J.D. 1973. Vigour determination in soybean seeds by multiple criteria. Crop Sci. 13: 630-633.

Anonymous, 2016. Pulses in India: Retrospect and Prospects. Ministry of Agriculture and farmers welfare, Govt. Of India., pp: 83.

Ashwini, C. and Giri, G.K. 2014 (a). Detection and transmission of seed borne mycoflora in green gram and effect of different fungicides. Int. J. Adv. Res. 2(5): 11821186.

Ashwini, C. and Giri, G.K. 2014 (b). Control of seed borne fungi in green gram and black gram through bioagents. Int. J. of applied biology and pharmaceutical tech. 5(3): 168170.

Brayford, D. 1996. Fusarium oxysporium fsp. dianthi. IMI Descriptions of fungi and Bacteria. 1264: 1-2.

Dabbas, M.R., Singh, D.P. and Prakash H.G. 2009. Effect of seed dressing chemical and Seedling infection of mungbean against Alternaria alternata. Int. J. of plant protec. 2(2): 214-216.

Fakir, G.A., Hossain, I. and Parmanik, B.K. 2001. Research finding of BAU on seed borne diseases of pulses. Proc. National Workshop on seed Pathol. BAU. pp: 1-10.

Fatma, F., Kamal, A. and Shrivastava, A. 2017. Morphotoxicity of fungicides mancozeb on two Genotypes of Vigna. Int. J. of Botany. 7(2): 8-14.

Gandhi, A. and Raghuchander, T. 2001. Effect of spore suppression and partially purified toxin of Fusarium oxysporium fsp. coriandrii on seed germination and seedling vigour of coriander. Ann. Pl. Prot. Sci. 9: 142-144.

Gawade, S.B., Zanjare, S.R., Suryawanshi, A.V. and Shelar, V. R. 2016. Efficacy of Bioagents and botanicals on seed mycoflora and seed quality in mungbean. [ Vigna radiata (L.) Wilzek]. Agric. Sci. Digest. 36(1): 30-34.

Geetanjali, K., Giri, G.K. and Patil, A.N. 2014. Detection of seed borne fungi in mungbean from rain affected seed. J. Pl. Dis. Sci. 9(1): 91-93.

Jain, S.C., Pathak, V.N. and Jain, K.L. 1996. Effect of fungal toxic metabolites on seed germination and seedling growth of pearl millet. Indian J. Mycol. Pl. Pathol. 26: 8789.

Javaid, A. and Anjum, T. 2006. Fungi associated with seeds of some economically important Crops in Pakistan - a review. PJST, 1(8\&9): 55-61.

Kandhre, A.S. 2014. Seed borne fungi and their effect on seed health of green gram. Biosci. Disc. 5(2): 251-255.

Mandhare, V.K., Gawade, S.B. and Suryawanshi, A.V. 2010. Efficacy of bioagents and botanicals extract seed treatment against seed borne fungi in soybean. J. Pl. Pathol.

Pan, S., Khalko, S. and Das, A. 2010. Effect of 
some fungicides on seed mycoflora, germination viability and their persistace in treated seeds. The J. of Plant Protec. Sci. 2(1): 59-64.

Paul, Y.S. 1992. Studies on seed borne mycoflora of coriander with special reference to stem Gall in Himachal Pradesh. Pl. Dis. Res. 7: 19-23.

Prajapati, R.K., Kartha, K.K., Joshi, R.K. and Nema, K.G. 2003. A Rhizoctonia disease of mung (Phaseolus aureus) Proxb. JNKVV Res. 3: 40-43.

Prasad, B.K. 1983. Seed borne fungi of coriander, their pathoginicity and control. Indian J. mycol. Pl. Pathol. 12: 238-239.

Prokinova, E. and Buresova, V. 1996. The effect of micromycetes from the seeds on germination of pea and barley seeds. Rostlima Vyroba. 42: 457-462.

Rahman, S., Suchada, V. and Srichuwong, S. 2002. Control of seed borne Macrophomina phaseolina in mungbean through biological seed treatment. J. of Agril. 18(1): 33-39.

Rahman, S., Vearasilp, S. and Srichuwong, S. 1999. Detection of seed borne fungi in mungbean and blackgram seeds. J.of Sus. Tech. Dev. in crop produc. pp. 1-3.

Rajeshwari, B. and Kumari, K.V.S.M. 2009. Bioagents and fungicides for the management of Seed and seedling diseases of soybean. Indian J. of Pl. Pathol. 37(2): 127-131.

Rawal, P. and Singh, B. 2015. Detection, pathogenic potential and Transmission of seed borne microflora associated with opium poppy (Papaver somniferum L.) seeds. J. Mycol. Pl. Pathol. 45: 372-393.

Sarita, Buts, A.K. and Singh, R. 2014. Study of seed borne mycoflora of Mungbean treated with potassium nitrate during storage. J. Adv. Appl. Sci. Res. 5 (6):11-13.

Sethuraman, K., Revathy, N. and Manivannan, M. 2003. Efficacy of biocontrol micro organisms on root rot of black gram caused by Macrophomina phaseolina (Tassi) Goid. Legume Research. 26 (3): 218-220.

Shekhar, 2016. Studies on mycoflora derived seed leachate as an indicator of seed health in pulses M. Sc. (Ag.) Thesis submitted to Indira Gandhi Krishi Vishwavidyalaya, Raipur (C.G.).

Shrivastava, R.N. and Gupta, J.S. 1981. Seed mycoflora from Indian seed lots from Cosmos bipinatus and their control. Indian Phyotopath. 34(3): 383-385.

Singh, S., Sinha, A. and Mishra J. 2014. Evaluation of different treatment on the occurrences of seed borne fungi of mungbean Vigna radiata (L.) Wilczek seed. Academic Journals. 9(44): 3300-3304.

Singh, S.D., Rawal, P., Shekawat, N.S. and Lodha, P.C. 2002. Management of mungbean (Vigna radiata (L.) Wilzeck) seed mycoflora by seed dressing fungicides. J. Mycol. Plant Pathol., 23(1): 149.

Suramwar, S.P., Vaddoria, M.A., Mehta, D.R. and Patel, N.B. 2014. Influence of pre-sowing microbial and fungicides seed treatment on seed quality in mungbean (Vigna radiata L.)Wilzeck. An Int. e- Journal. 3(1): 97104.

Tak, P.S., Bassi, G. and Singh, N. 2015. Management of seed borne mycoflora of mungbean by Priming with botanicals and Pseudomonas fluorescens. PL.Dis. Res. 30(1): 34-39.

Teama, E.A.E., Hemida, S.K. and Abdel Mallek, A.Y. 2000. Seed viability of mungbean in relation to seed-borne fungi and artificial fungal infestation. Ass. J. Agric. Sci. 31(5): 187-201.

Vidhyasekaran, P., Sabramanian, C.L. and Govindaswamy, C.V. 1970. Production of toxin by Seed borne fungi and its role in paddy field spoilage. Indian Phytopath. 23: 518-526.

\section{How to cite this article:}

Santoshi Pradhan, N. Lakpale, P.K. Tiwari and Ashish Pradhan. 2017. Effect of Seed Treatment and Seed Borne Mycoflora on Vigour of Mungbean [Vigna radiata (L.) Wilczek] Grown in Agro - Climatic Zones of Chhattisgarh. Int.J.Curr.Microbiol.App.Sci. 6(11): 1946-1954. doi: https://doi.org/10.20546/ijcmas.2017.611.231 